\title{
Comparison of biogenic volatile organic compound emissions from broad leaved and coniferous trees in Turkey
}

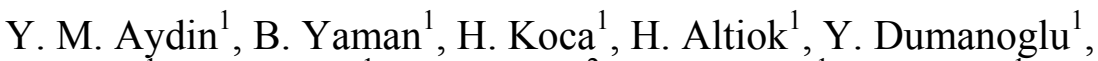

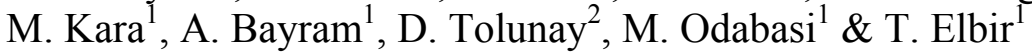 \\ ${ }^{I}$ Department of Environmental Engineering, Faculty of Engineering, \\ Dokuz Eylul University, Turkey \\ ${ }^{2}$ Department of Soil Science and Ecology, Faculty of Forestry, \\ Istanbul University, Turkey
}

\begin{abstract}
Biogenic volatile organic compound (BVOC) emissions from thirty-eight tree species (twenty broad leaved and eighteen coniferous) grown in Turkey were measured. BVOC samples were collected with a specialized dynamic enclosure technique in forest areas where these tree species are naturally grown. In this method, the branches were enclosed in transparent nalofan bags maintaining their natural conditions and avoiding any source of stress. The air samples from the inlet and outlet of the bags were collected on an adsorbent tube containing Tenax. Samples were analyzed using a thermal desorption (TD) and gas chromatography mass spectrometry (GC/MS) system. Sixty-five BVOC compounds were analyzed in five major groups: isoprene, monoterpenes, sesquiterpens, oxygenated sesquiterpenes and other oxygenated VOCs. Emission factors were calculated and adjusted to standard conditions $\left(1000 \mu \mathrm{mol} / \mathrm{m}^{2} \mathrm{~s}\right.$ photosynthetically active radiation-PAR and $30^{\circ} \mathrm{C}$ temperature). Consistent with the literature, broad leaved trees emitted mainly isoprene while the coniferous trees emitted mainly monoterpenes. Even though fir species are coniferous trees, they emitted significant amounts of isoprene in addition to monoterpenes. Oak species showed a large inter-species variability in their emissions. Pine species emitted mainly monoterpenes and substantial amounts of oxygenated compounds.

Keywords: BVOC emissions, dynamic enclosure system, emission factor, Turkey.
\end{abstract}




\section{Introduction}

Gas exchange between atmosphere and biosphere makes these mediums strongly interlinked components of the Earth's ecosystem while most of the organisms synthesize and emit various biogenic volatile organic compounds (BVOCs). Plant based emissions are the most prominent BVOCs as they have widely investigated by researchers in recent studies [1-5]. It was estimated that the global BVOC emissions from plants accounts for 1,150 Tg C/year, almost twice the anthropogenic VOC emissions (Guenther et al . [6]) . Forest areas cover 31.1\% of the Earth's surface and also $27 \%$ of Turkey's $\left(215,370 \mathrm{~km}^{2}\right)[7,8]$ making them significant BVOC sources. Therefore, specifying the emission factors of the trees is crucial. Wilske et al. [9] investigated isoprenoid emissions of eight tropical tree species of Southeastern Asia, and also Bao et al. [10] screened ten Japanese plants for their biogenic emissions and many other species were investigated within numerous of studies and several well-organized BVOC measurement projects such as; ECHO (Emission and Chemical Transformation of Biogenic Volatile Organic Compounds) (Spirig et al. [11]), BEMA (Biogenic Emissions in the Mediterranean Area) (Versino [12]). A large number of plants were studied and the emission factors are available on the relevant databases.

BVOCs; including isoprene, terpenes (monoterpenes, sesquiterpenes) and oxygenated VOCs (alcohols, aldehydes, ketones, and acetates) are important for atmospheric chemistry since they contribute to secondary organic aerosol formation and play an important role in the oxidative capacity of the atmosphere $[13,14]$. Furthermore, BVOCs have effects on the chemical composition and physical characteristics of the atmosphere as they photochemically react with nitrogen oxides $\left(\mathrm{NO}_{\mathrm{x}}\right)$ and forming tropospheric ozone [15-17]. Therefore, leaf/needle, branch, canopy or ecosystem level measurements with various methods and equipments are being conducted to determine the biogenic emissions in global or regional scales around the world [18-20].

Vegetative emissions have a large inter-species and temporal/seasonal variability [21]. Thus the reliability and the comparability of the reported values are biased by the diverse experimental conditions used. Previously, researchers have determined biogenic emissions at leaf/needle or branch scale mostly using the dynamic enclosure method [4]. In this method, a leaf/needle, branch or a whole plant is enclosed in a transparent chamber. The main requirements for an enclosure system are maintaining inside-chamber conditions (e.g. temperature, $\mathrm{CO}_{2}$ concentration, humidity, photosynthetically active radiation [PAR]) similar to ambient air. Tambunan et al. [3] measured isoprene emission from 42 indigenous and exotic tropical trees in subtropic Okinawa, Japan, Sabillon and Cremades [22] investigated monoterpene emissions from two of the most typical Mediterranean tree species (Quercus ilex and Pinus pinea) and Padhy and Varshney [23] measured isoprene emissions of nine commonly growing tree species in Delhi, India using the dynamic enclosure technique. A number of analyzed BVOCs in literature were generally limited because of the experimental and analytical difficulties. Measurement procedures were performed in related studies focusing on variables such as, species, season, plant tissues, measurement 
techniques, environmental conditions (e.g. temperature, humidity, PAR, $\mathrm{CO}_{2}$ ) directly affecting biogenic emissions [24, 25]. Harrison et al. [26] determined both monoterpene and isoprene emissions from a fir species (Abies borisii-regis), addressing PAR and temperature effects on emissions and Vuorinen et al. [27] discussed the effects of ambient $\mathrm{CO}_{2}$ and $\mathrm{O}_{3}$ concentrations on BVOC emissions of silver birch trees. As commonly reported in literature, isoprene and monoterpenes are the most abundant BVOCs. Isoprene is mostly produced photosynthetically by broad-leaved trees and its emissions depend on light intensity and temperature while monoterpenes from coniferous species predominantly depend on temperature [10, 28, 29]. However, for several tree species unexpected emission patterns were determined. For instance a fir species (Abies borisii-regis) found to be a strong isoprene emitter Harrison et al. [26] and Holly Oak (Quercus ilex) emitted monoterpenes as much as typical coniferous trees.

There is no investigation that directly focused on BVOC emissions in Turkey's forests. In this study, 15 field campaigns were performed for 38 tree species in different regions of Turkey during two summers (2011-2012) to measure BVOC emissions. The main objectives of the present study were, (i) to determine the BVOC (isoprene, monoterpenes, sesquiterpenes, oxygenated compounds and others) emission factors from 38 tree species those naturally and widely grown in Turkey and (ii) to investigate the BVOC compositions and compare the emissions from broad-leaved and coniferous species.

\section{Materials and methods}

\subsection{Sampling program and collection}

On-site measurements were conducted between June and October 2011, and May and November 2012 in different forest areas where the natural habitats of 38 trees are located. Trees including 31 common and 7 endemic species (18 of coniferous and 20 broad-leaved trees) representing the biological tree diversity of Turkey were sampled (Figure 1). Three middle-aged healthy (i.e., no pest or diseases affected, well-developed trees, not obstructed by neighboring plants, favorable soil conditions and no other biotic/abiotic stress sources) representative-trees of each species were selected for sampling. Measurements were conducted during daytime and collected samples were kept at $4{ }^{\circ} \mathrm{C}$ until they were analyzed. BVOC samples collected simultaneously from two different branches of each tree. Thus, the emission rates for each species were calculated by averaging six values (from 3 trees $\mathrm{x} 2$ branches) for each BVOC.

BVOCs were sampled by dynamic branch enclosure method. Selected branches were enclosed into transparent Nalofan bags and air composition in bags was sampled with Tenax-filled adsorbent tubes. Temperature, humidity, $\mathrm{CO}_{2}$ concentration and PAR were monitored and recorded in ambient air and in the enclosure. Conditions in the enclosure were regulated to provide similar conditions to ambient air. The chamber was purged continuously by an inflow provided by a diaphragm pump and regulated/measured with a mass flow 


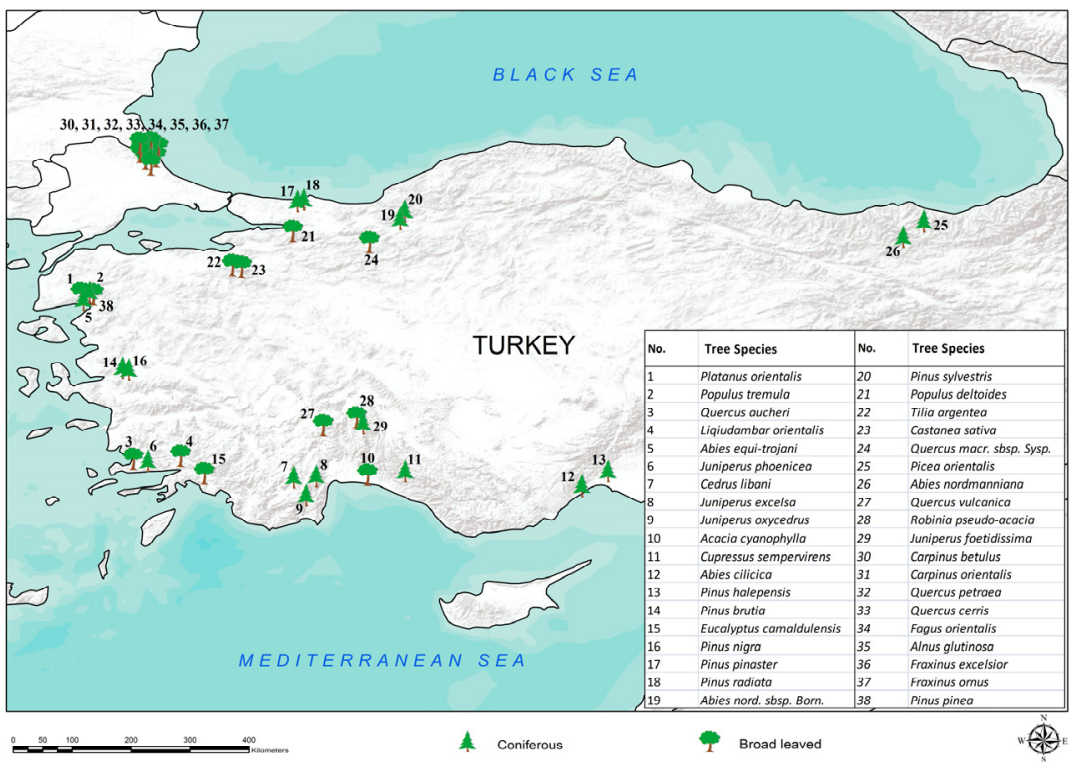

Figure 1: $\quad$ Sampling sites.

controller (MFC) (Aalborg DFC26) at a flow rate of $350 \mathrm{l} / \mathrm{h}$. The excess air was vented through a by-pass line. The inflow air was conditioned using three sequential columns containing silica gel, potassium iodide (KI) and activated carbon to supply VOCs, ozone and humidity-free air to the chamber. All the components in the system in contact with air flows (tubings, connection ports, internal surfaces of the pumps and MFCs) were chemically inert (mostly Teflon or Teflon-coated). Cold water provided by a circulating water bath was circulated in the bag through a spiral Teflon tubing to prevent the increase in temperatures inside the bag. For the first two hours of experiment the enclosure system was purged to provide steady-state conditions. Then, the air was sampled simultaneously from the inlet and outlet lines for an hour. Tenax TA filled sorbent tubes were used to adsorb BVOCs. At the end of the sampling, tubes were removed, tightly closed and placed into their containers. Then, total weight and leaf area of the leaves in the enclosure were measured in field. Dry weight was determined by oven-drying of the leaves for two days at $60^{\circ} \mathrm{C}$. Using these data both dry weight and leaf area based emission factors were calculated.

\subsection{BVOC analysis}

Before sampling, Tenax-filled sorbent tubes were conditioned with a $40 \mathrm{ml} / \mathrm{min}$ flow of helium gas at $240^{\circ} \mathrm{C}$ for 10 minutes and they were kept in their containers.

Samples were analyzed for 65 compounds (isoprene, 21 monoterpenes, 15 sequiterpenes, 3 oxygenated sesquiterpenes, and 25 oxygenated VOCs) with a gas chromatograph (GC) (Agilent $6890 \mathrm{~N}$, Agilent, Wilmington, DE, USA) 
equipped with a mass selective detector (Agilent 5973 inert MSD, Agilent, Wilmington, DE, USA) and a thermal desorber (Tekmar, Aerotrap 6000, USA). Samples were desorbed for $10 \mathrm{~min}$ at $240^{\circ} \mathrm{C}$ with $40 \mathrm{ml} / \mathrm{min}$ helium. Internal trap temperature during sample desorption was $35^{\circ} \mathrm{C}$. The trap was desorbed for 1 $\min$ at $240^{\circ} \mathrm{C}$. Then, it was baked for $10 \mathrm{~min}$ at $250^{\circ} \mathrm{C}$. Valve oven and transfer line temperatures of the thermal desorber were $200^{\circ} \mathrm{C}$.

The chromatographic column was HP5-MS (30 m, $0.25 \mathrm{~mm}, 0.25 \mu \mathrm{m})$ and the carrier gas was helium at $1 \mathrm{ml} / \mathrm{min}$ flowrate and $37 \mathrm{~cm} / \mathrm{s}$ linear velocity. The split ratio was $1: 40$. The inlet temperature was $240^{\circ} \mathrm{C}$. Temperature program for VOCs was: initial oven temperature $40^{\circ} \mathrm{C}$, hold $3 \mathrm{~min}, 40^{\circ} \mathrm{C}$ to $120^{\circ} \mathrm{C}$ at $5 \mathrm{C} / \mathrm{min}$, hold $5 \mathrm{~min}, 120^{\circ} \mathrm{C}$ to $240^{\circ} \mathrm{C}$ at $30^{\circ} \mathrm{C} / \mathrm{min}$, hold $3 \mathrm{~min}$. Ionization mode was electron impact (EI). Ion source, quadrupole, and GC/MSD interface temperatures were 230,150 , and $280^{\circ} \mathrm{C}$, respectively. GC/MS was operated at "scan" and "selected ion monitoring" modes simultaneously. Compounds were identified based on their retention times (within \pm 0.05 minutes of the retention time of calibration standard), target and qualifier ions and were quantified using the external standard calibration procedure.

Six levels of VOC solutions were prepared in methanol as the calibration standards. Thermal desorption tubes used for calibration were loaded by spiking with $1 \mu \mathrm{l}$ of the calibration standards $[30,31]$. Then, these were run at specified conditions to calibrate the Thermal desorber-GC-MS. In all cases, linear fit was good with $\mathrm{r}^{2}>0.999$.

\subsection{Quality assurance/quality control}

Instrumental detection limits (IDL) were determined from linear extrapolation, based on the lowest standard in calibration curve and using the area of a peak having a signal/noise ratio of 3 . The quantifiable VOC amounts were between 5.7 (p-cymene) and $295 \mathrm{pg}$ (guaiol). Blank Tenax tubes were routinely placed in the field to determine if there was any contamination during sample handling and preparation. The limit of detection of the method (LOD, pg) was defined as the mean blank mass plus three standard deviations. Instrumental detection limit was used for the compounds that were not detected in blanks. LOD ranged between 7.5 (trans-dihydro-b-terpineol)-1455 (crotonaldehyde) pg. Average VOC amounts in blanks were 5\% of the amounts found in samples. Samples were blank-corrected by subtracting the average blank amount from the sample amount. Using an average sampling volume of $0.009 \mathrm{~m}^{3}$, limit of detection of the method ranged between 0.0008 (trans-dihydro-b-terpineol) and 0.16 (crotonaldehyde) $\mu \mathrm{g} / \mathrm{m}^{3}$.

The system performance was confirmed daily by analyzing a midrange calibration standard. If the relative standard deviation from the initial calibration was $<10 \%$, system was recalibrated. Analytical precision determined from three pairs of duplicate samples ranged between $2-5 \%$. 


\section{Results and discussions}

Emission factors for 65 analyzed compounds were calculated and normalized for $1000 \mu \mathrm{mol} / \mathrm{m}^{2} \mathrm{~s}$ and $30^{\circ} \mathrm{C}$ as suggested by Guenther et al. [32]. BVOCs were grouped as isoprene, monoterpenes, sesquiterpenes, oxygenated sesquiterpenes and oxygenated compounds. Table 1 summarizes the calculated average BVOC emissions for each species.

Isoprene and monoterpenes were the two predominant BVOCs for all species while the other three BVOC groups contributed less to total emissions. Platanus orientalis had the highest isoprene emission $(27 \mu \mathrm{g} / \mathrm{g} \mathrm{h})$. It was also the strongest BVOC emitter with a total emission factor of $27.1 \mu \mathrm{g} / \mathrm{g} \mathrm{h}$. Two ash species, Fraxinus ornus and Fraxinus excelsior were the weakest emitters with emission factors of 0.033 and $0.038 \mu \mathrm{g} / \mathrm{g} \mathrm{h}$. The highest monoterpene emitter was Castanea sativa with an average monoterpene emission factor of $14.4 \mu \mathrm{g} / \mathrm{g} \mathrm{h}$.

\subsection{Emissions from broad-leaved species}

Broad-leaved trees are largely known as isoprene emitters due to their high photosynthetic activities [10]. Fifteen out of twenty studied broad-leaved species emitted mainly isoprene, consistent with general broad-leaved emitting characteristics. However, half of them emitted comparatively low total BVOC amounts ranging from 0.033 to $0.946 \mu \mathrm{g} / \mathrm{g} \mathrm{h}$. Sweet Chestnut showed a clearly different emitting pattern as a broad-leaved tree with the highest monoterpene emitting rate of $14.4 \mu \mathrm{g} / \mathrm{g} \mathrm{h}$. Oaks might be considered as the most prevalent broad-leaved trees those largely investigated in the literature and classified as predominant isoprene emitters [33-35]. In Turkey, approximately $30 \%$ of all forests are covered by 18 oak species and 5 of them were investigated in the present study. Quercus macranthera subsp. syspirensis, Quercus vulcanica and Quercus petraea obviously indicated the typical oak emission characteristics with the isoprene rates of $19.2,9.79$ and $9.63 \mu \mathrm{g} / \mathrm{g}$ h, respectively. However oaks showed a wide inter-species variability in their emissions ranging from 0.157 to $19.4 \mu \mathrm{g} / \mathrm{g}$ h for total BVOCs.

\subsection{Emissions from coniferous species}

Pine, juniper and fir species were the three main genera comprising 15 of the 18 studied coniferous trees. Monoterpenes were the prominent compounds for all coniferous species except four species (Abies nordmanniana, Abies cilicica, Pinus pinea and Pinus radiata). Abies cilicica anomalously emitted $14.1 \mu \mathrm{g} / \mathrm{g} \mathrm{h}$ isoprene which equals to $91.2 \%$ of its total emissions. Pine species were mostly prone to emit monoterpenes and oxygenated compounds while no significant isoprene emissions were observed (Figure 2). Pinus brutia had the highest total BVOC emitting rate of $12.3 \mu \mathrm{g} / \mathrm{g} \mathrm{h}$ that $10.6 \mu \mathrm{g} / \mathrm{gh}$ of it consisted of monoterpenes. Four juniper species showed regular emission patterns and their emission factors were relatively low ranging from 0.468 to $2.20 \mu \mathrm{g} / \mathrm{g} \mathrm{h}$ and their total emissions dominated by monoterpenes. Fir species had completely different 
Table 1: $\quad$ Emission factors $(\mu \mathrm{g} / \mathrm{g} \mathrm{h})$ for BVOC groups of broad-leaved and coniferous trees (normalized to $1000 \mu \mathrm{mol} / \mathrm{m} 2 \mathrm{~s}$ PAR and $30^{\circ} \mathrm{C}$ temperature).

\begin{tabular}{|c|c|c|c|c|c|c|}
\hline \multicolumn{7}{|c|}{ Emission factors $(\mu \mathrm{g} / \mathrm{g}$ h) } \\
\hline & Isoprene & $\mathbf{M T}^{\mathrm{a}}$ & $\mathbf{S Q}^{\mathbf{b}}$ & $\mathbf{O S}^{\mathbf{c}}$ & $O^{d}$ & Total \\
\hline \multicolumn{7}{|c|}{$\begin{array}{l}\text { Broad leaved trees } \\
\end{array}$} \\
\hline Fagus orientalis & 0.047 & 0.020 & 0.003 & 0.00156 & 0.023 & 0.095 \\
\hline Quercus petraea & 9.63 & 0.012 & 0.007 & 0.00169 & 0.037 & 9.69 \\
\hline Quercus cerris & 0.079 & 0.020 & 0.005 & 0.01035 & 0.042 & 0.157 \\
\hline Quercus vulcanica & 9.79 & 0.063 & 0.022 & 0.00008 & 0.060 & 9.93 \\
\hline Quercus aucheri & 0.028 & 0.879 & 0.006 & 0.00014 & 0.033 & 0.946 \\
\hline Quercus macr. sbsp. sysp. & 19.2 & 0.070 & 0.067 & 0.00032 & 0.090 & 19.4 \\
\hline Carpinus orientalis & 0.102 & 0.009 & 0.006 & n.d & 0.034 & 0.150 \\
\hline Carpinus betulus & 0.060 & 0.061 & 0.013 & 0.0005 & 0.136 & 0.270 \\
\hline Alnus glutinosa & 0.018 & 0.133 & 0.003 & n.d & 0.054 & 0.209 \\
\hline Populus tremula & 22.4 & 0.235 & 0.015 & 0.00074 & 0.034 & 22.7 \\
\hline Populus deltoides & 4.72 & 0.070 & 0.022 & 0.00021 & 0.022 & 4.83 \\
\hline Castanea sativa & 0.378 & 14.4 & 0.033 & 0.00027 & 0.281 & 15.1 \\
\hline Fraxinus excelsior & 0.011 & 0.011 & 0.0007 & 0.00002 & 0.014 & 0.038 \\
\hline Fraxinus ornus & 0.014 & 0.005 & 0.006 & 0.00003 & 0.008 & 0.033 \\
\hline Tilia argentea & 0.077 & 0.483 & 0.005 & 0.00037 & 0.089 & 0.655 \\
\hline Eucalyptus camaldulensis & 5.14 & 0.169 & 0.078 & 0.00091 & 0.414 & 5.80 \\
\hline Acacia cyanophylla & 0.196 & 0.099 & 0.014 & 0.00070 & 0.042 & 0.351 \\
\hline Robinia pseudo-acacia & 12.4 & 0.075 & 0.013 & 0.00354 & 0.041 & 12.5 \\
\hline Platanus orientalis & 27.0 & 0.027 & 0.029 & 0.00040 & 0.102 & 27.1 \\
\hline Liqiudambar orientalis & 15.0 & 1.31 & 0.061 & n.d & 0.164 & 16.5 \\
\hline \multicolumn{7}{|c|}{ Coniferous trees } \\
\hline Pinus brutia & 0.022 & 10.6 & 0.166 & 0.00630 & 1.48 & 12.3 \\
\hline Pinus nigra & 0.051 & 3.48 & 0.017 & 0.00017 & 0.344 & 3.89 \\
\hline Pinus sylvestris & 0.183 & 1.57 & 0.027 & 0.00043 & 0.734 & 2.51 \\
\hline Pinus halepensis & 0.046 & 3.81 & 0.049 & 0.00575 & 0.590 & 4.50 \\
\hline Pinus pinaster & 0.015 & 0.583 & 0.022 & 0.00224 & 0.171 & 0.793 \\
\hline Pinus radiata & 0.108 & 0.329 & 0.007 & 0.00068 & 0.361 & 0.805 \\
\hline Pinus pinea & 0.084 & 1.11 & 0.006 & 0.00171 & 2.20 & 3.40 \\
\hline Picea orientalis & 2.37 & 3.90 & 0.098 & 0.00014 & 0.439 & 6.81 \\
\hline Cedrus libani & 0.010 & 0.526 & 0.045 & 0.00008 & 0.363 & 0.945 \\
\hline Juniperus excelsa & 0.025 & 2.03 & 0.032 & n.d & 0.105 & 2.20 \\
\hline Juniperus phoenicea & 0.005 & 0.611 & 0.019 & 0.00012 & 0.059 & 0.695 \\
\hline Juniperus oxycedrus & 0.010 & 0.502 & 0.047 & 0.00054 & 0.057 & 0.616 \\
\hline Juniperus foetidissima & 0.028 & 0.398 & 0.005 & 0.00003 & 0.037 & 0.468 \\
\hline Cupressus sempervirens & 0.049 & 0.403 & 0.039 & 0.00064 & 0.278 & 0.769 \\
\hline Abies nordmanniana & 2.26 & 0.329 & 0.089 & 0.00008 & 0.190 & 2.87 \\
\hline Abies cilicica & 14.1 & 1.16 & 0.074 & 0.00011 & 0.135 & 15.5 \\
\hline Abies equi-trojani & 1.35 & 1.66 & 0.009 & 0.00024 & 0.554 & 3.57 \\
\hline Abies nord. sbsp. born. & 1.50 & 2.30 & 0.036 & 0.00012 & 0.502 & 4.34 \\
\hline
\end{tabular}

n.d.: not detected, ${ }^{a}$ Monoterpenes, ${ }^{b}$ Sesquiterpenes, ${ }^{c}$ Oxygenated sesquiterpenes, ${ }^{d}$ Oxygenated compounds. 
emitting behaviours as coniferous trees with their high isoprene emissions, such that 91.2 and $78.8 \%$ of their total emissions were isoprene for Abies cilicica and Abies nordmanniana, respectively (Figure 3).

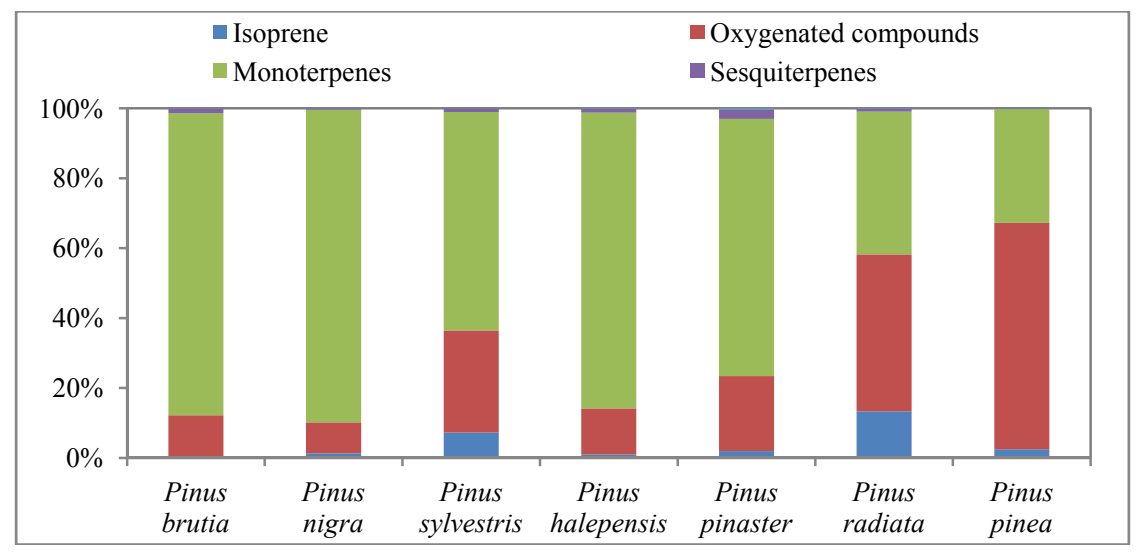

Figure 2: $\quad$ Percentage distribution of BVOC emissions for pine species.

\subsection{Comparison of measured emission factors with the literature}

Isoprene is a photosynthetic compound that is mostly produced by broad-leaved trees and has an emission dependence on light intensity and temperature while monoterpenes predominantly depend on temperature in coniferous species [10, $28,29]$. In this study, results were clearly comparable with previously reported values and emitting patterns. Isoprene and monoterpenes dominated the total BVOC compositions of broad leaved trees. However, emissions of coniferous species might consist of different variety of BVOCs. Padhy and Varshney [23] reported $9.90 \mu \mathrm{g} / \mathrm{g} \mathrm{h}$ isoprene emission for Eucalyptus globulus while in the present study isoprene emission for Eucalyptus camaldulensis was found as $5.14 \mu \mathrm{g} / \mathrm{g}$ h. There were two oak species that showed unexpectedly low isoprene emissions. Similarly Quercus myrsinaefolia was studied by Bao et al. [10] and they reported no significant isoprene emissions. Quercus ilex is one of the most frequently studied oak in the literature and largely characterized as a strong monoterpene emitter compared to the other oak species and broad-leaved trees $[22,36]$. Quercus aucheri in this study had a monoterpene emission of $0.879 \mu \mathrm{g} / \mathrm{g} \mathrm{h}$ consisting $92.9 \%$ of the total emissions making it a monoterpene emitter. Hakola et al. [37] measured isoprene and monoterpene emissions of a poplar species (Populus tremula) as 13.6 and $0.73 \mu \mathrm{g} / \mathrm{g} \mathrm{h}$, respectively, indicating a similar emission pattern observed for the poplar species investigated in the present study (Table 1).

Komenda and Koppmann [38] reported that monoterpene emissions ranged between 0.06 to $3.70 \mu \mathrm{g} / \mathrm{g}$ h for Pinus sylvestris. Kempf et al. [39] measured $3.15 \mu \mathrm{g} / \mathrm{gh}$ monoterpene from Picea abies. Owen et al. [40] reported monoterpene and isoprene emission rates of 0.96 and $0.08 \mu \mathrm{g} / \mathrm{g} \mathrm{h}$, respectively 


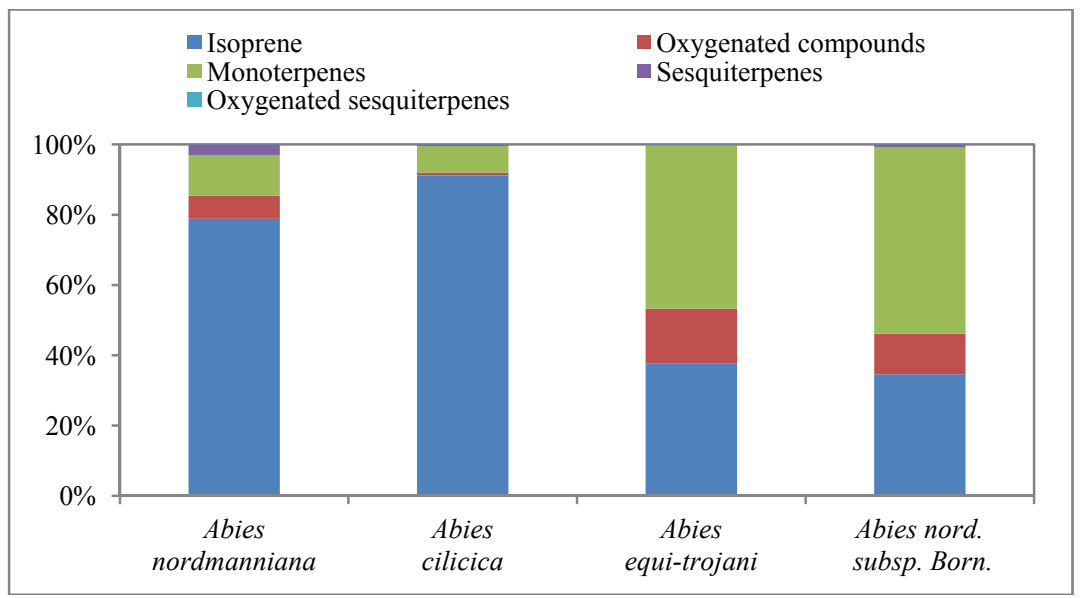

Figure 3: Percentage distribution of BVOC emissions for fir species.

for Juniperus oxycedrus. Most of the values in the present study were clearly comparable to those given in previous studies for coniferous trees. Some coniferous trees having an atypical emitting behavior such as Abies boriisi-regis with a high isoprene emission rate of $18.4 \mu \mathrm{g} / \mathrm{g} \mathrm{h}$ were also reported in literature [26] similar to Abies cilicica subsp. isaurica included in the present study.

\section{Conclusions}

Results of this study indicated that vegetative emissions are mostly composed of isoprene and monoterpenes while sesquiterpenes, oxygenated sesquiterpenes and oxygenated compounds were emitted relatively in low quantities. Total emissions 17 of the 38 investigated tree species were $<1 \mu \mathrm{g} / \mathrm{gh}$ (Table 1). According to BVOC emission compositions, isoprene and monoterpenes had the largest portion for broad leaved and coniferous species respectively. However, unexpected emitting patterns observed for some species. Characteristically ash and juniper species were weak BVOC emitters and oak species showed the largest inter-species variability. Emission factors determined in this study have an implication for the estimation of total BVOC emissions for Turkey. These emissions will be used as an input for future air quality modelling studies.

\section{Acknowledgement}

This study was supported by The Scientific and Technological Research Council of Turkey (TUBITAK) (Project no: TUB/110Y302).

\section{References}

[1] Komenda, M., Parusel, E., Wedel, A. \& Koppmann, R., Measurements of biogenic VOC emissions: sampling, analysis and calibration. Atmospheric Environment, 35(12), pp. 2069-2080, 2001. 
[2] Geron, C., Guenther, A., Greenberg, J., Loescher, H.W., Clark, D. \& Baker, B., Biogenic volatile organic compound emissions from a lowland tropical wet forest in Costa Rica. Atmospheric Environment, 36(23), pp. 3793-3802, 2002.

[3] Tambunan, P., Baba, S., Kuniyoshi, A., Iwasaki, H., Nakamura, T., Yamasaki, H. \& Oku, H., Isoprene emission from tropical trees in Okinawa Island, Japan. Chemosphere, 65(11), pp. 2138-2144, 2006.

[4] Ortega, J. \& Helmig, D., Approaches for quantifying reactive and lowvolatility biogenic organic compound emissions by vegetation enclosure techniques - part A. Chemosphere, 72(3), pp. 343-364, 2008.

[5] Raisanen, T., Ryyppo, A. \& Kellomaki, S., Monoterpene emission of a boreal Scots pine (Pinus sylvestris L.) forest. Agricultural and Forest Meteorology, 149(5), pp. 808-819, 2009.

[6] Guenther, A., Hewitt, C.N., Erickson, D., Fall, R., Geron, C., Graedel, T., Harley, P., Klinger, L., Lerdau, M., Mckay, W.A., Pierce, T., Scholes, B., Steinbrecher, R., Tallamraju, R., Taylor, J. \& Zimmerman, P., A GlobalModel of Natural Volatile Organic-Compound Emissions. Journal of Geophysical Research-Atmospheres, 100(D5), pp. 8873-8892, 1995.

[7] OGM, www.ogm.gov.tr

[8] WorldBank, http://data.worldbank.org/indicator/AG.LND.FRST.ZS

[9] Wilske, B., Cao, K.F., Schebeske, G., Chen, J.W., Wang, A. \& Kesselmeier, J., Isoprenoid emissions of trees in a tropical rainforest in Xishuangbanna, SW China. Atmospheric Environment, 41(18), pp. 37483757, 2007.

[10] Bao, H., Kondo, A., Kaga,A., Tada, M., Sakaguti, K., Inoue, Y., Shimoda, Y., Narumi, D. \& Machimura, T., Biogenic volatile organic compound emission potential of forests and paddy fields in the Kinki region of Japan. Environmental Research, 106(2), pp. 156-169, 2008.

[11] Spirig, C., Neftel, A., Ammann, C., Dommen, J., Grabmer, W., Thielmann, A., Schaub, A., Beauchamp, J., Wisthaler, A. \& Hansel, A., Eddy covariance flux measurements of biogenic VOCs during ECHO 2003 using proton transfer reaction mass spectrometry. Atmospheric Chemistry and Physics, 5, pp. 465-481, 2005.

[12] Versino, B., BEMA: A European commission project on biogenic emissions in the Mediterranean area - Introduction and objectives. Atmospheric Environment, 31, pp. 1-3, 1997.

[13] Andreae, M.O. \& Crutzen, P.J., Atmospheric aerosols: biogeochemical sources and role in atmospheric chemistry. Science, 276(5315), pp. 10521058, 1997.

[14] Fuentes, J.D., Lerdau, M., Atkinson, R., Baldocchi, D., Bottenheim, J.W., Ciccioli, P., Lamb, B., Geron, C., Gu, L., Guenther, A., Sharkey, T.D. \& Stockwell, W., Biogenic hydrocarbons in the atmospheric boundary layer: a review. Bulletin of the American Meteorological Society, 81(7), pp. 1537-1575, 2000. 
[15] Fehsenfeld, F., Emissions of volatile organic compounds from vegetation and the implications for atmospheric chemistry. Global Biogeochemical Cycles, 6, pp. 389-430, 1992.

[16] Roselle, S.J., Effects of biogenic emission uncertainties on regional photochemical modeling of control strategies. Atmospheric Environment, 28(10), pp. 1757-1772, 1994.

[17] Simpson, D., Hydrocarbon reactivity and ozone formation in Europe. Journal of Atmospheric Chemistry, 20(2), pp. 163-177, 1995.

[18] Guenther, A., Greenberg, J., Harley, P., Helmig, D., Klinger, L., Vierling, L., Zimmerman, P. \& Geron, C., Leaf, branch, stand and landscape scale measurements of volatile organic compound fluxes from US woodlands. Tree Physiology, 16(1-2), pp. 17-24, 1996.

[19] Singsaas, E.L., \& Sharkey, T.D., The effects of high temperature on isoprene synthesis in oak leaves. Plant Cell and Environment, 23(7), pp. 751-757, 2000.

[20] Holzke, C., Hoffmann, T., Jaeger, L., Koppmann, R. \& Zimmer, W., Diurnal and seasonal variation of monoterpene and sesquiterpene emissions from Scots pine (Pinus sylvestris L.). Atmospheric Environment, 40(17), pp. 3174-3185, 2006.

[21] Fall, R., Biogenic Emissions of Volatile Organic Compounds from Higher Plants. Topics in Reactive hydrocarbons in the atmosphere, ed. C.N. Hewitt, Academic Press: San Diego, California, pp. 41-96, 1999.

[22] Sabillon, D. \& Cremades, L.V., Diurnal and seasonal variation of monoterpene emission rates for two typical Mediterranean species (Pinus pinea and Quercus ilex) from field measurements-relationship with temperature and PAR. Atmospheric Environment, 35(26), pp. 4419-4431, 2001.

[23] Padhy, P.K. \& Varshney, C.K., Isoprene emission from tropical tree species. Environmental Pollution, 135(1), pp. 101-109, 2005.

[24] Graus, M., Schnitzler, J.P., Hansel, A., Cojocariu, C., Rennenberg, H., Wisthaler, A. \& Kreuzwieser, J., Transient release of oxygenated volatile organic compounds during light-dark transitions in grey poplar leaves. Plant Physiology 135(4), pp. 1967-1975, 2004.

[25] Dindorf, T., Kuhn, U., Ganzeveld, L. , Schebeske, G., Ciccioli, P., Holzke, C., Koble, R., Seufert, G. \& Kesselmeier, J., Significant light and temperature dependent monoterpene emissions from European beech (Fagus sylvatica L.) and their potential impact on the European volatile organic compound budget. Journal of Geophysical Research-Atmospheres, 111(D16), 2006.

[26] Harrison, D., Hunter, M.C., Lewis, A.C., Seakins, P.W., Nunes, T.V. \& Pio, C.A., Isoprene and monoterpene emission from the coniferous species Abies Borisii-regis - implications for regional air chemistry in Greece. Atmospheric Environment, 35(27), pp. 4687-4698, 2001.

[27] Vuorinen, T., Nerg, A.M., Vapaavuori, E. \& Holopainen, J.K., Emission of volatile organic compounds from two silver birch (Betula pendula Roth) clones grown under ambient and elevated $\mathrm{CO}_{2}$ and different $\mathrm{O}_{3}$ concentrations. Atmospheric Environment, 39(7), pp. 1185-1197, 2005. 
[28] Moukhtar, S., Couret, C., Rouil, L. \& Simon, V., Biogenic volatile organic compounds (BVOCs) emissions from Abies alba in a French forest. Science of the Total Environment, 354(2-3), pp. 232-245, 2006.

[29] Dominguez-Taylor, P., Ruiz-Suarez, L.G., Rosas-Perez, I., HernandezSolis, J. M. \& Steinbrecher, R., Monoterpene and isoprene emissions from typical tree species in forests around Mexico City. Atmospheric Environment, 41(13), pp. 2780-2790, 2007.

[30] Odabasi, M., Ongan, O. \& Cetin, E., Quantitative analysis of volatile organic compounds (VOCs) in atmospheric particles. Atmospheric Environment, 39(20), pp. 3763-3770, 2005.

[31] Dincer, F., Odabasi, M. \& Muezzinoglu, A., Chemical characterization of odorous gases at a landfill site by gas chromatography-mass spectrometry. Journal of Chromatography A, 1122(1-2), pp. 222-229, 2006.

[32] Guenther, A.B., Zimmerman, P.R., Harley, P.C., Monson, R.K. \& Fall, R., Isoprene and monoterpene emission rate variability - model evaluations and sensitivity analyses. Journal of Geophysical Research-Atmospheres, 98(D7), pp. 12609-12617, 1993.

[33] Steinbrecher, R., Hauff, K., Rabong, R. \& Steinbrecher, J., Isoprenoid emission of oak species typical for the Mediterranean area: source strength and controlling variables. Atmospheric Environment, 31, pp. 79-88, 1997.

[34] Baugh, W., Klinger, L., Guenther, A. \& Geron, C., Measurement of oak tree density with Landsat TM data for estimating biogenic isoprene emissions in Tennessee, USA. International Journal of Remote Sensing, 22(14), pp. 2793-2810, 2001.

[35] Geron, C., Harley, P. \& Guenther, A., Isoprene emission capacity for US tree species. Atmospheric Environment 35(19), pp. 3341-3352, 2001.

[36] Grote, R., Mayrhofer, S., Fischbach, R.J., Steinbrecher, R., Staudt, M. \& Schnitzler, J.P., Process-based modelling of isoprenoid emissions from evergreen leaves of Quercus ilex (L.). Atmospheric Environment, 40, pp. S152-S165, 2006.

[37] Hakola, H., Rinne, J. \& Laurila, T., The hydrocarbon emission rates of tealeafed willow (Salix phylicifolia), silver birch (Betula pendula) and European aspen (Populus tremula). Atmospheric Environment, 32(10), pp. 1825-1833, 1998.

[38] Komenda, M. \& Koppmann, R., Monoterpene emissions from Scots pine (Pinus sylvestris): field studies of emission rate variabilities. Journal of Geophysical Research-Atmospheres, 107(D13), 2002.

[39] Kempf, K., Allwine, E., Westberg, H., Claiborn, C. \& Lamb, B., Hydrocarbon emissions from spruce species using environmental chamber and branch enclosure methods. Atmospheric Environment, 30(9), pp. 1381-1389, 1996.

[40] Owen, S., Boissard, C., Street, R.A., Duckham, S.C., Csiky O. \& Hewitt, C.N., Screening of 18 Mediterranean plant species for volatile organic compound emissions. Atmospheric Environment, 31, pp. 101-117, 1997. 